\title{
TURKEY CORONAVIRUS-MG10 INFECTION IN YOUNG TURKEY POULTS
}

\author{
Gomaa, M. H1., and Mansour, A. A2. \\ 1 Department of Virology, Faculty of Veterinary Medicine Kafrelsheikh University, \\ 2 Department of Anatomy, Faculty of Veterinary Medicine Kafrelsheikh University.
}

\begin{abstract}
The course of turkey coronavirus (TCoV) infection in young turkey poults was examined using a field isolate (TCoV-MG10) from a diarrheal disease outbreak on a commercial turkey farm. One day old and 25-day-old poults were inoculated orally with TCoV-MG10 to examine the effect of age on viral shedding. The presence of coronavirus particles measuring $105.8 \pm 21.8 \mathrm{~nm}$ in the cloacal contents was confirmed using transmission electron microscopy. The pattern of cloacal TCoV shedding was examined by RT PCR amplification of the nucleocapsid (N) gene fragment. Poults were found equally susceptible to TCoV infection at day of age and at 3 weeks of age and turkeys of either age shed virus in their feces starting as early as 1 day postinoculation up to 17 days post-inoculation. Infected birds had profound villus atrophy with some compensatory crypt hyperplasia at 5 to 7 days post infection ( 7 dpi).
\end{abstract}

\section{INTRODUCTION}

Turkey coronavirus (TCoV) is one of the most important viral agents causing diarrhea among turkey flocks. The complete genome sequence of a TCoV isolate from Ontario (27,657 bases) was determined (assigned as the reference sequence for TCoV GenBank (NC_010800) (Gomaa et al., 2008). TCoV causes high economic losses to the poultry 
producers through high morbidity, poor growth performance, and poor food conversion ratio as well as some mortality. Once this pathogen is introduced in a particular area, it is difficult to eliminate because of the nature of the virus and lack of effective control measures including vaccination. Peterson and Hymas identified TCoV in 1951 for the first time during an outbreak in a turkey farm in Washington State. The disease was initially called "mud fever" and subsequently "blue comb disease", based on the similarity in the clinical signs to avian monocytosis, which was known as the blue comb disease of chickens. TCoV was reported to cause severe problems in USA and Canada between 1951 and 1971. It was a highly costly disease, especially in Minnesota because of high mortality rates reaching upwards of $23 \%$ as well as the severe body weight losses (Nagaraja and Pomeroy, 1997,Guy et al., 2000). The disease was experimentally reproduced in turkey poults and a coronavirus was identified for the first time in 1973 (Ritchie et al., 1973; Panigrahy et al., 1973). TCoV has been incriminated as one of the most important agents associated with the poults enteritis and mortality syndrome (PEMS) (Barnes et al., 2000; Cavanagh et al., 2001). In Brazil in an outbreak of Poults enteritis and mortality syndrome (PEMS) has been recently identified. The affected birds showed a typical signs of coronavirus enteritis in the form of diarrhea, decrease in the body weight gain along with high mortality rates (Teixeira et al., 2007).

\section{MATERIAL AND METHODS}

Virus. TCoV-MG10 was isolated from turkey farm suffering from acute enteritis and diarrhea. The collected intestines were homogenized in PBS with mortar and pestle and then clarified by centrifugation at $1000 \times \mathrm{g}$ for 15 minutes. The supernatant was filtered through a $0.22-\mu \mathrm{m}$ 
membrane filter (Millipore, Bedford, MA) and the virus was titrated by RT-PCR. Virus-containing supernatant diluted 10-4 was able to produce a barely detectable PCR product of the expected $330 \mathrm{bp}$ in size. The same virus-containing inoculum was used throughout this study. The complete genomic sequence for this isolate is available (see Gomaa et al., 2008).

Experimental design. Thirty (30) one day old turkey poults have been used in this study. Poults were wing tagged and divided into 2 separately housed groups, 10 infected and 20 control birds. Day-old birds were orally inoculated with $100 \mu \mathrm{L}$ of clarified virus-containing supernatant. In the control group birds were orally given with $100 \mu \mathrm{L}$ of PBS. At 21 days of age, remaining poults in the infected group received a secondary challenge of TCoV-MG10 via both oral gavage and intramuscular injection (100 $\mu \mathrm{L}$ of clarified TCoV MG10 each). At 25 days of age, eight birds from the control group were moved to the room housing the infected poults and orally inoculated with TCoV MG10 as described above for the day of age poults. e in gene bank under the accession number NC_010800 (Gomaa et al, 2008).

\section{Cloacal swabs collection:}

Cloacal swabs were collected on days $1,3,5,7,14$, and 21 days post infection (dpi) for birds challenged at day of age and on days 1, 3, 5, 7, 14 and 17 dpi for poults challenged at 25 days of age. For birds rechallenged at 21 days of age, cloacal swabs were taken at 1, 3, 5, 7 and 14 days post-challenge. Swab contents were suspended in PBS by pressing repeatedly against the wall of the tube. The swabs were then removed and the suspension was centrifuged at $1,000 \times \mathrm{g}$ for 10 minutes at $4^{\circ} \mathrm{C}$. The supernatant was collected and then centrifuged at $2,000 \times \mathrm{g}$ at 
$4{ }^{\circ} \mathrm{C}$. The supernatant from the second centrifugation was collected and passed sequentially through a $0.45 \mu \mathrm{m}$ and then $0.2 \mu \mathrm{m}$ Millipore filters. The resulting filtrate was stored at $70^{\circ} \mathrm{C}$ until use for detection of virus by RT-PCR.

\section{RNA extraction, RT-PCR and PCR:}

RNA extraction was carried out from the filtered cloacal swab suspensions using Qiagen RNA mini-easy Kits (Qiagen, Valencia, CA) according to the manufacturers' instructions. Complementary DNA (cDNA) was generated with random hexamers and PCR with nuclocapsid gene-specific primers (NF1: 5' AGGGAAATTTTGGTGATGAC 3'; NR1: 5' ATGGGCGTCCTTGTGCTGTA 3') was carried out as previously described (Gomaa et al., 2008). PCR amplification products were separated by electrophoresis through a $1 \%$ agarose, stain with ethidium bromide and visualized by UV light. Reactions were considered positive for $\mathrm{TCoV}$ if an amplification product of $330 \mathrm{bp}$ was visible in the agarose gel. To confirm the identity of the amplicon as TCoV, randomly selected positive samples were purified using Qiagen PCR purification kits (Qiagen, Valencia, CA) and then sequenced using the NF1 and NR1 primers. The cDNA from each cloacal swab sample was also tested for turkey astrovirus using Astro-For: 5' AATAAGGTCTGCACAGGT 3' and Astro-Rev: 5' TGGCGGCGAACTCCTCAACA 3' primers (Sellers et al., 2004) as well as avian reovirus using ARV S4 P4: 5' GTGCGTG TTGGAGTTTC 3' and ARV S4 P5: 5' ACAAAGCCAGCCATRAT 3' primers (Bruhn et al., 2005). For all PCR reactions, both known positive and negative control samples were included for quality control. 


\section{Electron microscopy:}

Filtrate of cloacal swab samples or fecal samples were tested for the presence of the coronavirus particles using transmission electron microscopy. One drop of sample was placed on the top of the carboncoated Formvar grid, stained with $2 \%$ phosphotungstic acid and dried before examination in a Leo 912 ab electron microscope.

\section{Histopathological examination:}

Two birds from the control and infected groups were selected at random at 3,5, 7, 14 and 21 dpi for the collection of tissues. In total, twenty birds (10 infected birds and 10 age matched control birds) were subjected to necropsy and histopathological examination. Birds were examined for the presence of macroscopic lesions in the small and large intestines. Pieces of the duodenum, jejunum, ileum and ceca were collected in $10 \%$ buffered formalin and then processed for paraffin embedment and sectioning by standard methods. Sections (approximately 5 $\mu \mathrm{m}$ thick) were stained with haematoxylin and eosin stain (H\&E). Morphometric analysis of the intestinal villar architecture was conducted on tissues from all 20 birds.

\section{RESULTS}

\section{Clinical Observations:}

Birds inoculated at 2 days of age. Poults started developing clinical signs 2 dpi in the form of diarrhea, frothy droppings, ruffled feathers, and decreased food and water consumption. The morbidity rate reached $100 \%$ at 3dpi when clinical signs were most apparent . Two of 20 birds died at 3 dpi giving a mortality rate of $10 \%$ with the MG10 strain of $\mathrm{TCoV}$. The duration of diarrhea was 3 to 5 days in primary infections in birds inoculated at 2 days of age 


\section{Monitoring the virus shedding with RT-PCR:}

All 10 birds inoculated with TCoV at day of age developed diarrhea 3 days after being inoculated with TCoV-MG10 orally; diarrhea persisted for 2 days and then began to subside so that no birds were showing diarrhea by $11 \mathrm{dpi}$. Two severely affected turkey poults died at $3 \mathrm{dpi}$. RT-PCR for TCoV, turkey astrovirus and avian reovirus was performed on cloacal swabs containing fecal material collected from 10 poults before infection (day of age) and at 1, 3, 5, 7, 11, 14, 21 dpi (Figure 1 and Table 1). TCoV specific amplicons were detected in 3 of 10 birds at $1 \mathrm{dpi}$, in 8 of 10 birds at $3 \mathrm{dpi}$ and in all birds by 5 dpi. Shedding of TCoV as determined by TCoV specific RT PCR continued in 4 birds until 14 dpi but had ceased by 21 dpi in all turkeys infected on day of age. Poults that were reinoculated (challenged orally and via IM injection) at 21 days of age did not develop diarrhea. Faint TCoVspecific amplicons were detected using TCoV specific RT PCR in cloacal swabs in 2 of 8 of these challenged birds at 1 day postinoculation and in 1 of 8 poults at 2 days post-inoculation. At 3 days post-inoculation and thereafter, none of the poults challenged with TCoV-MG10 shed virus detectable using RT-PCR. Six out of eight poults infected for the first time at 25 days developed diarrhea by 3 days post-infection which was resolved by 9 dpi. Cloacal swabs and fecal material were collected at 1, 3, 5, 7, 11, 14 and 17 days post-infection (dpi). TCoV was detected in 2 of 8 birds at 1 dpi, in 4 of 8 birds at 3 dpi and in all birds by 5 dpi. Shedding continued in 3 birds until 14 dpi and 
one poult was still shedding $\mathrm{TCoV}$ at $17 \mathrm{dpi}$ when the experiment was terminated (Table 1).Turkey astrovirus and avian reovirus were not detected in the virus preparation used to inoculate birds or cloacal swabs or feces from any birds throughout the study (data not shown).

\section{Detection of virus particles using electron microscopy:}

Viral particles measuring $105.8 \pm 21.8 \mathrm{~nm}$ (range $85157 \mathrm{~nm}, \mathrm{n}=9$ ) morphologically similar to coronaviruses were observed by electron microscopy in cloacal swabs and clarified fecal samples (Figure 2).

\section{Necropsy Observations and Histopathology:}

Poults that were inoculated at 2 days of age were sampled at random at 3, 5, 7, 14 and 20 dpi (2 poults from each of the infected and uninfected groups). During the necropsy examination of infected and control poults selected 3, 5 or $7 \mathrm{dpi}$, the intestines were swollen and filled with yellow frothy digesta. The walls of the intestines were thin and pale compared to uninfected control poults of the same age. At 14 and $21 \mathrm{dpi}$, there were no obvious macroscopic lesions visible in the infected poults and their intestinal contents appeared comparable to the uninfected control poults sampled the same day. Microscopically, the most obvious difference between the infected and control poults was the reduced villar heights in the infected birds. At 3 dpi, some evidence of villar atrophy with reduced villus height and limited infiltration into the lamina propria was seen in both infected poults (Figure 3). By 5 dpi, infiltration of the lamina propria, particularly surrounding the crypts was pronounced and there was evidence of sloughing of epithelial cells and some fusion of adjacent villi 
Gomaa, M. H. \& Mansour, A. A.

Table (1): Turkey coronavirus (Tco-MG10) shedding detected by RT-PCR of cloacal swabs from turkey poults inoculated orally.

\begin{tabular}{|c|c|c|c|c|}
\hline $\begin{array}{c}\text { Challenge Dose } \\
\text { and Day }\end{array}$ & $\begin{array}{l}\text { Days post- } \\
\text { inoculation }\end{array}$ & Age (Days) & Control Poults & Infected Poults \\
\hline \multirow{7}{*}{$\begin{array}{l}\text { Challenged with } \\
\text { TcoV at } 2 \text { days } \\
\text { of age }\end{array}$} & 0 & 2 & $0 / 10$ & $0 / 10$ \\
\hline & 1 & 3 & $0 / 10$ & $3 / 10$ \\
\hline & 3 & 5 & $0 / 10$ & $8 / 10$ \\
\hline & 5 & 7 & $0 / 10$ & $8 / 8$ \\
\hline & 7 & 9 & $0 / 10$ & $8 / 8$ \\
\hline & 14 & 16 & $0 / 10$ & $4 / 8$ \\
\hline & 21 & 23 & $0 / 10$ & $0 / 8$ \\
\hline \multirow{7}{*}{$\begin{array}{l}\text { Challenged with } \\
\text { TcoV at } 28 \text { days } \\
\text { of age }\end{array}$} & 0 & 28 & $0 / 8$ & $0 / 8$ \\
\hline & 1 & 29 & $0 / 8$ & $2 / 8$ \\
\hline & 3 & 31 & $0 / 8$ & $4 / 8$ \\
\hline & 5 & 33 & $0 / 8$ & $8 / 8$ \\
\hline & 7 & 35 & $0 / 8$ & $8 / 8$ \\
\hline & 14 & 42 & $0 / 8$ & $3 / 8$ \\
\hline & 16 & 44 & $0 / 8$ & $1 / 8$ \\
\hline
\end{tabular}

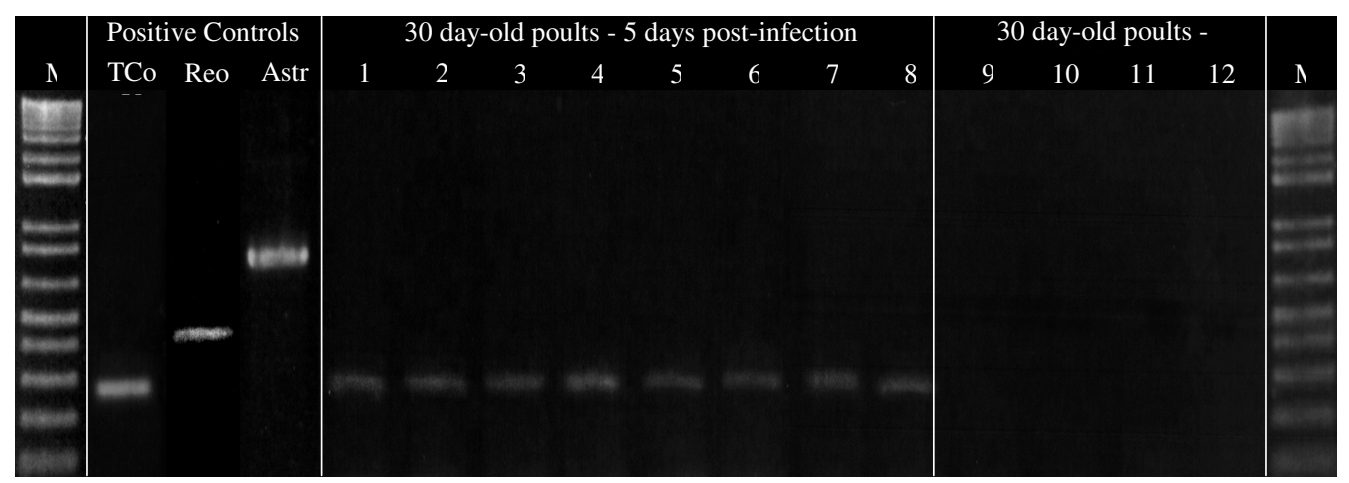

Fig. (1): Turkey coronavirus (TCoV-MG10) shedding detected using RT-PCR with TCoV-specific primers NF1 and NR1. Positive control samples for turkey coronavirus (TCoV), avian reovirus (Reo) and turkey astrovirus (Astro) showed amplification products of 330bp, 437bp and $830 \mathrm{bp}$, respectively (left panel). RT-PCR from 4 cloacal swab samples obtained from 30 day old control poults demonstrated no amplification products (lanes 9-12, right panel) whereas 8 cloacal swab samples obtained from poults of the same age infected 5 days previously with $\mathrm{TCoV}$ orally each demonstrated a TCoV-specific amplicon of 330bp (lanes 1-8, center panel; M, DNA size markers).

Kafrelsheikh Vet. Med. J. Vol. 7 No. 1 (2009) 


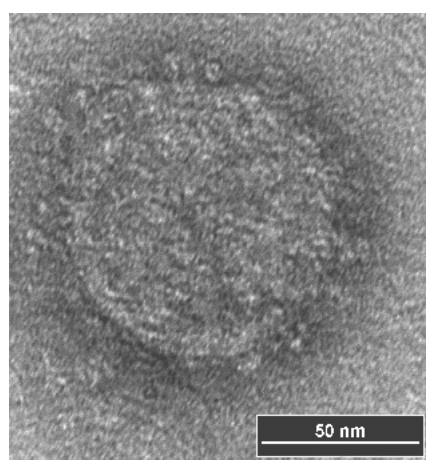

Fig. (2): Electron micrographs of negatively stained turkey coronavirus obtained from the cloacal swabs of infected turkey poults at 7 days postinfection (Scale bar $=50 \mathrm{~nm})$.

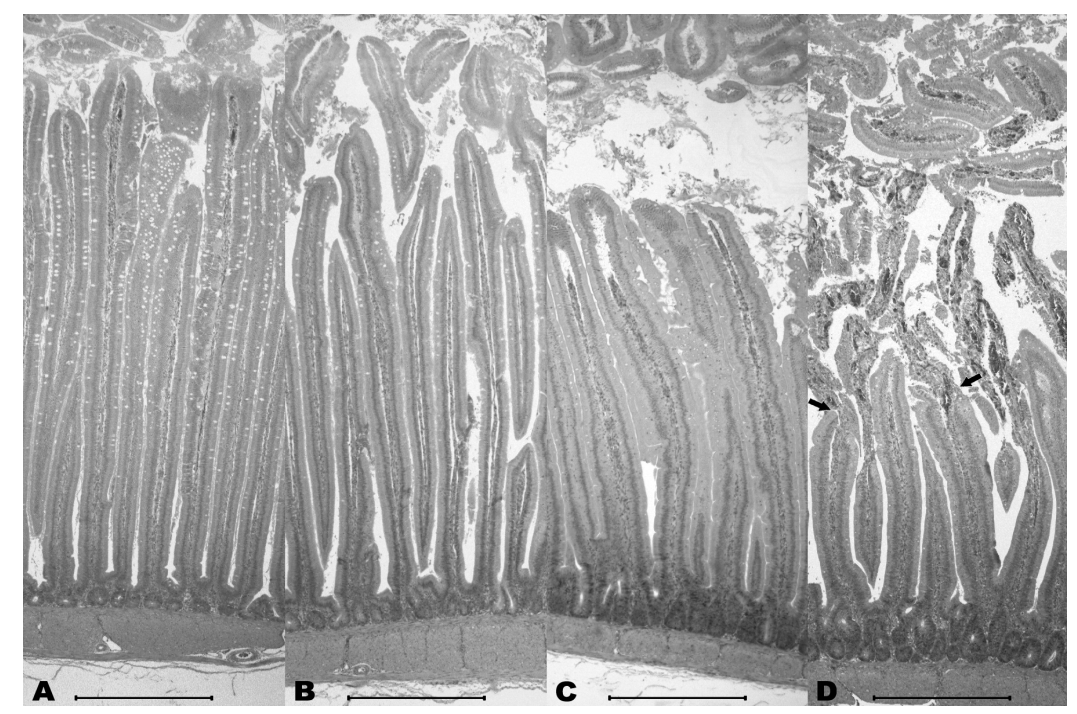

Fig. (3): Histological appearance of the duodenal mucosa of young turkey poults (bars $=500 \mu \mathrm{m})$. A, Uninfected turkey poult at 6 days of age; $\mathrm{B}$, infected turkey poult at 4 days of age ( $3 \mathrm{dpi})$ had nearly normal appearance; $\mathrm{C}$, infected turkey poult at 6 days of age $(5 \mathrm{dpi})$ demonstrating cellular infiltration of the lamina propria of the villi and surrounding the crypt. There was some shortening of the villi with modest increase in crypt depth; $\mathrm{D}$, infected turkey poult at 8 days of age (7 dpi) showing significant villus shortening with sloughing of denuded villar lamina propria (arrows) and some increase in crypt depth. Infiltration of the lamina propria, especially surrounding the crypts, with lymphocytes and monocytes was evident. 


\section{DISCUSSION}

Turkey coronavirus has been incriminated as one of the important etiological agents associated with Poult Enteritis and Mortality Syndrome or PEMS (Carver et al., 2001; Cavanagh, 2005). PEMS is believed to result from infection with one or more of several enteric viruses (e.g. Heggen-Peay et al., 2002), bacteria and/or protozoa but the exact cause of the syndrome is not known; although not absolutely required for the development of PEMS, TCoV is certainly associated with this disease syndrome (Brown et al., 1997; Carver et al., 2001; Teixeira et al., 2007). Economic losses of around US\$136 million have been reported for the 5 year period from 1991 to 1996 in turkey flocks in the USA as a result of PEMS outbreaks (Barnes et al., 2000) and the syndrome has recently been described from Great Britain for the first time (Culver et al., 2006).

The goals of the current study were study the course of TCoV infections in young turkey poults using an isolate (TCoV-MG10) from a diarrheal disease outbreak on an Ontario commercial turkey farm. The pattern of shedding of TCoV particles in the cloacal contents was established by RT PCR of the N-gene. In the present study, TCoV could be detected using TCoV-specific RT PCR in the feces and cloacal swabs as early as $1 \mathrm{dpi}$. By $3 \mathrm{dpi}, 50 \%$ or more of inoculated birds began to shed the virus and by 5 dpi all bird were shedding TCoV. Viral shedding persisted in about $50 \%$ of the birds at 14 dpi and ceased by 21 dpi (see Figures 4 and 5). These observations are consistent with an earlier study in which shedding was observed for up to 2 weeks post-inoculation for the TCoV ATCC V R 911 isolate (Ismail et al., 2003), but shorter than shedding of up to 7 weeks demonstrated for the TCoV NC95 isolate (Breslin et al., 2000). Using indirect fluorescent antibody methods, $\mathrm{TCoV}$ antigen could be detected within intestinal epithelial cells of the 
intestinal tract for up to 28 days in young turkey poults (Patel el al., 1975). The duration and course of TCoV shedding did not differ between day of age poults and birds first infected at 25 days of age. The relatively brief period of viral shedding and the presence of clinical signs in most infected poults may explain why $\mathrm{TCoV}$ was not detected in any fecal samples obtained from commercial turkey barns that contained turkeys considered healthy or normal by field personnel (Pantin-Jackwood et al., 2007; 2008). Attempts at reinfection of poults previously exposed to $\mathrm{TCoV}$ resulted in no resumption of clinical signs. Except for faint bands detected in cloacal swabs from a small percentage of birds on the first and second day following oral inoculation with TCoV that could have resulted from viral particles in the inoculum that passed through the digestive tract, there was no evidence of $\mathrm{TCoV}$ shedding resulting from endogenous viral replication. This suggests that protective immunity was acquired after a single infection with $\mathrm{TCoV}$ and as early as 21 days after a primary infection. This observation was consistent with reports that birds recovered from $\mathrm{TCoV}$ infection showed resistance to further infection with the same virus (Pomeroy et al., 1975: Nagaraja and Pomeroy., 1997). TCoV-specific antibodies detected as early as 7 days post-infection in poults challenged at day of age or 25 days of age are likely to contribute to the resistance of turkeys to reinfection with TCoV. Virus neutralization studies using IBV indicate that antibody levels against the S1 glycoprotein are correlated with virus-neutralizing antibody titres (Mondal and Naqi, 2001).

In summary, the results of these experimental infections suggest that turkey poults are equally susceptible to $\mathrm{TCoV}$ infections at day of age and at 3 weeks of age and those turkeys of either age shed virus in their feces for a similar duration 


\section{REFERENCES}

- Barnes, H.J., Guy, J.S. \& Vaillancourt, J.P. (2000). Poult enteritis complex. Revue Scientifique et Technique de l'Office International des Epizooties, 19, 565-588.

- Breslin, J.J., Smith, L.G., Barnes, H.J., \& Guy, J.S. (2000). Comparison of virus isolation, immunohistochemstry and reverse transcriptase polymerase chain reaction procedures for detection of turkey coronavirus. Avian Diseases, 44, 624-631.

- Brown,T.P., Garcia,A. \& Kelley,L. (1997). Spiking mortality of turkey poults: 1. Experimental reproduction in isolation facilities. Avian Diseases, 41, 604-609.

- Bruhn, S., Bruckner, L. \& Ottiger, H.P. (2005). Application of RTPCR for the detection of avian reovirus contamination in avian viral vaccines. Journal of Virological Methods, 123, 179-186.

- Carver,D.K., Vaillancourt,J.P.,Stringham,M., Guy, J.S. \& Barnes, H. J. (2001). Mortality patterns associated with poult enteritis mortality syndrome (PEMS) and coronaviral enteritis in turkey flocks raised in PEMS-affected regions. Avian Diseases, 45, 985-991.

- Cavanagh, D. (2001). A nomenclature for avian coronavirus isolates and the question of species status. Avian Pathology, 30, 109-115.

- Cavanagh, D., Mawditt, K., Sharma, M., Drury, S. E., Ainsworth, H. L., Britton, P. and Gough, R. E. (2001). Detection of a coronavirus from turkey poults in Europe genetically related to infectious bronchitis virus of chickens. Avian Pathol, 30, 355-368.

- Cavanagh, D. (2005). Coronavirus in poultry and other birds. Avian Pathology, 34, 439-448. 
- Culver, F., Dziva, F., Cavanagh, D. \& Stevens, M.P. (2006). Poult enteritis and mortality syndrome in turkeys in Great Britain. Veterinary Record, 159, 209-210.

- Gomaa, M.H., Barta, J.R., Ojkic, D. \& Yoo, D. (2008a). Complete genome sequence of turkey coronavirus. Virus Research, 135, 237 246.

- Guy,J. S., Smith, L.G., Breslin, J. J., Vaillancourt, J. P. and Barnes, H. $J$. (2000). High mortality and growth depression experimentally produced in young turkeys by dual infection with enteropathogenic Escherichia coli and turkey coronavirus. Avian Dis. 44: 105113.

- Heggen-Peay, C.L., Qureshi,M.A.,Edens, F.W., Sherry, B., Wakenell, P.S., O'Connell, P.H. \& Schat, K.A. (2002). Isolation of a reovirus from poult enteritis and mortality syndrome and its pathogenicity in turkey poults. Avian Diseases, 46, 32-47.

- Ismail,M.M., Tang,A.Y. \& Saif, Y.M. (2003). Pathogenicity of turkey coronavirus in turkeys and chickens. Avian Diseases, 47, 515522.

- Mondal, S.P. \& Naqi, S.A. (2001). Maternal antibody to infectious bronchitis virus: its role in protection against infection and development of active immunity to vaccine. Veterinary Immunology and Immunopathology, 79, 31-40.

- Nagaraja,K.\& Pomeroy, B.S. (1997). Coronaviral enteritis of turkeys (bluecomb disease) In B.W. Calnek, H.J. Barnes, C.W. Beard, L.R.

- McDougald \& Y.M. Saif. (1997). Diseases of Poultry $10^{\text {th }}$ end (pp. 686-692). Ames: Iowa State University Press.

- Panigrahy, B., Naqi, S.A. \& Hall, C.F . (1973). Isolation and characterization of viruses associated with transmissible enteritis (bluecomb) of turkeys. Avian Diseases, 17, 430-438. 
- Pantin-Jackwood, M.J, Day, J.M., Jackwood, M.W. \& Spackman, E. (2008). Enteric viruses detected by molecular methods in commercial chicken and turkey flocks in the United States between 2005 and 2006. Avian Diseases, 52, 235-244.

- Pantin-Jackwood,M.J., Spackman, E., Day, J.M. \& Rives, D. (2007). Periodic monitoring of commercial turkeys for enteric viruses indicates continuous presence of astrovirus and rotavirus on the farms. Avian Diseases, 51, 674-680.

- Patel, B.L., Deshmukh, D.R. \& Pomeroy, B.S. (1975). Fluorescent antibody test for rapid diagnosis of coronaviral enteritis of turkeys (bluecomb). American Journal of Veterinary Research, 36, 12651267.

- Peterson, E.H. \& Hymas, T.A. (1951). Antibiotics in the treatment of unfamiliar turkey disease. Poultry Science, 30, 466-468.

- Pomeroy, B.S., Larsen, C.T. Deshmukh, D.R. \& Patel, B.L. (1975). Immunity to transmissible (coronaviral) enteritis of turkeys (blue comb). American Journal of Veterinary Research, 36, 553-555.

- Ritchie,A.E.,Deshmukh,D.R., Larsen, C.T. \& Pomeroy, B.S. (1973). Electron microscopy of coronavirus-like particles characteristic of turkey blue comb disease. Avian Diseases, 17, 546-558.

- Sellers, H.S, Koci, M.D, Linnemann E, Kelley, L.A \& SchultzCherry, S. (2004). Development of a multiplex reverse transcriptionpolymerase chain reaction diagnostic test specific for turkey astrovirus and coronavirus. Avian Diseases, 48, 531-539.

- Teixeira, M.C.B, Luvizotto, M.C.R., Ferrari, H.F., Mendes, A.R., da Silva, S.E.L. \& Cardoso, T.C. (2007). Detection of turkey coronavirus in commercial turkey poults in Brazil. Avian Pathology, 36, 29-33. 


\title{
إصابة كتاكيت الرومي بفيروس الكورونا MG10 من نوع
}

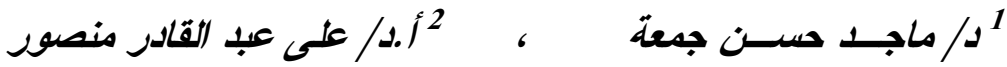 \\ 1 قسم الفيرولوجيا كلية الطب البيطري - جامعة كفر الثيخ \\ 2 قسم التثريح والأجنة كلية الطب البيطري- جامعة كفر الشيخ
}

لقد تمت دراسة فترة إصابة كتاكيت الرومى بفيروس الكورونا باستخدام عتره معزولة من كتاكيت رومى تعانى من اسهالات شديدة خلال هذه الدراسة تم عدوة كتاكيت الرومى عمر يوم وكذلك عمر 25 يوم عن طريق الفم بنفس الفيروس المعزول سابقاً وكذلك لدراسة تأثنير عمر الكتاكيت على فترة إفر از الفيروس فى براز الكتاكيت المحقونة المصابة طو ال فترة العدوى . لقد استقرت هذه الدراسة عن التأكد من وجود الفيروس فى براز الكتاكيت المعدية بذات الفيروس بواسطة الميكروسكوب الإلكتروني ونتج عن هذا الفحص الكثف عن وجود جزيئات فى بر از الكتاكيت المصابة فى نفس شكل وحجم الفيروسات من نوع الكورونا بالإضافة إلى ذلك تم تأكيد وجود الفيروس فى براز الكتاكيت المصابة أيضاً باستخدام تقنية تفاعل العلمى المتسلسل والمعكوس باستخدام جزء من النيكليوكابسيد بروتين جين

طبقاً لنتائج هذا البحث فقد وجدنا أن الكتاكيت عمر يوم وكذللك عمر ثلاثة أسابيع يمكن أن تصاب بفيروس الكورونا على حد سواء بالإضافة إلى تأكيد وجود الفيروس فى براز الكتاكيت المعدية بفيروس الكورونا ابتداء من بوم و احد بعد العدوى وحتى 17 يوم من تاريخ بداية العدوى بالفيروس.

الكتاكيت المعدية بذات الفيروس كانت تعانى من تقدم فى الخملات الموجودة فى الأمعاء الدقيقة وذلك عن طريث الفحص بالميكروسكوب لعينات الأنسجة من الأمعاء الدقيقة للكتاكيت المعدية بالفيروس. 